Journal of Marine Systems

July 2018, Volume 183, Pages 32-41

http://dx.doi.org/10.1016/i.jmarsys.2018.03.009

http://archimer.ifremer.fr/doc/00435/54611/

(c) 2018 Elsevier B.V. All rights reserved.

\title{
Feeding of Greenland halibut (Reinhardtius hippoglossoides) in the Canadian Beaufort Sea
}

\author{
Giraldo Carolina ${ }^{1,{ }^{*}}$, Stasko Ashley ${ }^{2}$, Walkusz Wojciech ${ }^{3,4}$, Majewski Andrew ${ }^{3}$, Rosenberg Bruno ${ }^{3}$, \\ Power Michael ${ }^{2}$, Swanson Heidi ${ }^{2}$, Reist James D. ${ }^{3}$
}

${ }^{1}$ Ifremer, Laboratoire Ressources Halieutiques, 150 Quai Gambetta BP 699, F-62321, Boulogne sur mer, France

${ }^{2}$ University of Waterloo, 200 University Ave., Waterloo, ON, Canada

${ }^{3}$ Freshwater Institute, Fisheries and Oceans Canada, 501 University Crescent, Winnipeg, MB R3T 2N6, Canada

${ }^{4}$ Institute of Oceanology, Polish Academy of Sciences, Powstancow Warszawy 55, 81-712 Sopot,

Poland

* Corresponding author : Carolina Giraldo, email address : carolina.giraldo@ifremer.fr

\begin{abstract}
:
Trophic patterns for Greenland Halibut are reported for the first time in the Canadian Beaufort Sea and Amundsen Gulf $(n=269)$. Samples were collected from 2012 to 2014 on the upper $(300-500 \mathrm{~m})$ and lower continental slope $(750-1500 \mathrm{~m})$ and were analyzed for stomach contents, stable isotopes ratios and fatty acids (FA). Stomach contents indicated that Arctic Cod, Boreogadus saida, was the main prey ingested on the upper slope (50-94\% of total biomass) whereas Gelatinous Snailfish (Liparis fabricii) and Zoarcids (Lycodes spp.) dominated diets on the lower slope (17-62\% of total biomass). Stable isotope mixing models and FA analyses also identified benthopelagic fishes (i.e., Liparis spp., B. saida) as key prey and highlighted large dietary overlap among years and between the two depth categories. Greenland Halibut were characterized by relatively wide $\delta^{13} \mathrm{C}$ and narrow $\delta^{15} \mathrm{~N}$ ranges that suggested use of both pelagic and benthic energy sources and a piscivorous diet. Calanus-type markers such as $20: 1 \mathrm{n} 9$ dominated the FA ( $>20 \%$ of total FA) andemphasized the importance of pelagic-derived material in the diet. The contribution of pelagic and benthic-derived matter in the diet suggests that Greenland Halibut play a major role in the benthic-pelagic coupling for deep water communities (up to $1500 \mathrm{~m}$ ) in the Canadian Beaufort Sea.
\end{abstract}

\section{Highlights}

Greenland halibut's diet includes both pelagic and benthic sources. Low spatial (300 to $1500 \mathrm{~m}$ ) and temporal (years 2012-2014) variability were observed. Biomarkers (SIA, FA) indicate that halibut is a piscivorous/opportunistic feeder. Halibut plays a major role in the benthic-pelagic coupling in the Canadian Arctic. 
Keywords : Benthic-pelagic coupling, Trophic niche, Biomarkers, Arctic 


\section{Introduction}

Greenland Halibut (Reinhardtius hippoglossoides), a right-eyed flatfish of the family Pleuronectidae, is a deep water species of high commercial value in the northernmost parts of the Atlantic and Pacific oceans; it supports international fisheries off the coasts of Canada, Greenland, Iceland, Norway, Russia, Faroe Islands and USA (Barbeaux et al., 2012; Dwyer et al., 2016). This relatively large fish inhabits slope areas of continental shelves, deep water bays and channels as well as deep coastal fjords, and is generally found at depths of 200 to $2200 \mathrm{~m}$ and temperatures of $0-6^{\circ} \mathrm{C}$ (Bowering and Nedreaas, 2000). Recognized as a top predator feeding on the most abundant prey (Solmundsson, 2007), Greenland Halibut plays a key role in the structure and functioning of ecosystems (Stasko et al., 2016) and can be used as an indicator of ecosystem shifts (following prey availability) over time (Dwyer et al., 2010).

In the Canadian Beaufort Sea (CBS), the species was first recorded in 1995 by Chiperzak et al. (1995). In contrast to other arcto-boreal coastal areas, commercial fisheries in the CBS have been banned by agreement between the Canadian Government and Aboriginal groups until research can assure stocks sufficient to support sustainable harvesting by the Inuvialuit People. 
As a rich and relatively pristine environment, the Canadian Arctic is increasingly drawing interest from stakeholders looking to exploit its natural resources (e.g., fisheries, oil and gas) (Christiansen et al., 2014). Furthermore, global climate change, and particularly increasing summer temperatures in polar regions, are expected to reduce the sea-ice extent, providing more opportunities for offshore vessels to access marine resources and shipping opportunities (Barber et al., 2015).

Knowledge of trophic interactions is vital to determine how marine ecosystems function presently and to predict how they might respond to environmental change, as food web pathways change to facilitate ecosystem resilience and persistence (Libralato et al., 2014; Woodward et al., 2010). The feeding patterns of Greenland Halibut have been extensively studied over the years in waters where the species is of commercial value (e.g., North Atlantic, Link et al. (2002); Bering Sea, Barbeaux et al. (2012)). In general, individuals feed on small fishes, shrimp and cephalopods from both the benthic and pelagic realms, suggesting off-bottom predation (Bowering and Lilly, 1992; Solmundsson, 2007; Vollen et al., 2004), with larger fish > $700 \mathrm{~mm}$ having mainly a piscivorous diet. Pelagic feeding behavior in Greenland Halibut has been suggested over the past 50 years based on morphological traits (e.g., pigmentation of the blind side, and positioning of the left eye, de Groot 1970) or anecdotal information (e.g., Greenland Halibut being caught in pelagic waters with hand lines and salmon drift nets, Christensen and Lear 1977). Initially, pelagic feeding was thought to be restricted to young individuals aged 1 and 2 years, whose average lengths were below 300 mm (Jørgensen 1997a). Subsequent tagging experiments showed that larger individuals (up to $840 \mathrm{~mm}$ ) could also be found in pelagic waters (Vollen and Albert, 2008). However, such studies have also suggested that Greenland Halibut feed opportunistically on the most locally abundant prey. Opportunistic feeding implies that assumptions concerning the feeding ecology of unstudied stocks cannot be made (Pedersen and Riget, 1993). The 
contribution of pelagic-derived matter to the diet of Greenland Halibut, the variation in diet along environmental gradients such as depth, and the role of Greenland Halibut in facilitating active bentho-pelagic coupling for the CBS remains undetermined but is likely substantive.

Here, we draw on information gathered from the first comprehensive offshore trawling program in the CBS and Amundsen Gulf to update understanding regarding the ecology of Greenland Halibut in the region. Sampling took place during three consecutive summer cruises (years 2012 - 2014) and across two different depths categories: 300 to $500 \mathrm{~m}$ and 750 to $1250 \mathrm{~m}$ (herein referred to as the upper and lower slopes) where Greenland Halibut occurred. The objectives of this study were to: (1) assess the range of benthic habitat conditions occupied by Greenland Halibut in the CBS, including temperature, salinity, and depth; and, (2) assess the spatial and temporal variability of Greenland Halibut diet in the CBS. Because trophic interactions are fundamental to understanding the ecology of Greenland Halibut and the structure of offshore marine foodwebs, the second objective regarding diet was our primary focus.

\section{Methods}

2.1. Sampling area and processing

The CBS is defined by the broad, rectangular continental shelf, which extends approximately 120 $\mathrm{km}$ offshore to the $200 \mathrm{~m}$ isobath. Beyond this depth, the seafloor descends quickly to several thousand metres. The continental shelf is much narrower in the Amundsen Gulf, but the continental slope still descends quickly to maximum depths of about $600 \mathrm{~m}$. As a result, the CBS and Amundsen Gulf are a highly physically structured ecosystem comprised of different water masses as layers by depth (McLaughlin et al., 1996). Water masses are the result of cooccurrence of sea-ice melt, freshwater input from the Mackenzie River, incoming surface flows along the coast from the North Pacific Ocean via Bering Strait, subsurface polar gyres originating in the Atlantic Ocean, and deep Arctic Basin water. These layers provide distinct habitats within 
which particular types of fishes and other biota may associate (Majewski et al., 2013, 2017). Here, we consider the influence of depth on the dietary patterns of Greenland Halibut beyond the continental shelf, within a simplified representation of the vertical water mass structure of the CBS as generally described in McLaughlin et al. (1996). Briefly, the edge of the continental shelf ( 200m depth) marks the transition from overlying Pacific waters (i.e., Pacific water mass; approx. $-1{ }^{\circ} \mathrm{C}$ to $0{ }^{\circ} \mathrm{C}$; salinity 30 to 33.5 ) to warmer but more saline Atlantic water underneath (i.e., Atlantic water mass; up to $1.0^{\circ} \mathrm{C}$; salinity 33.5 to 34.95 ). Finally, the Atlantic water overlies the colder, highly saline waters of the Arctic water mass $\left(<0{ }^{\circ} \mathrm{C}\right.$, salinity around 34.9$)$.

Sampling was conducted by the Beaufort Regional Environmental Assessment Marine Fishes Project (BREA-MFP; Fisheries and Oceans Canada) aboard the commercial stern trawler F/V 'Frosti' from August to early September, 2012 - 2014. Greenland Halibut in the present study were collected in all three years. Other fishes and invertebrates were collected in 2012 and 2013 (Figure 1). Samples were collected between 300 to $1500 \mathrm{~m}$ depths via benthic trawling using a modified Atlantic Western IIA otter trawl. Sea-state permitting, full oceanographic profiles of the water column were conducted at most fishing stations using a Seabird conductivity, temperature and depth (CTD) probe (Sea-Bird Scientific, model SBE-25 s/n 0415, USA), equipped with an auxiliary oxygen sensor. Measurements were used to confirm the water mass distributions at sampling locations as described by McLaughlin et al. (1996) and Lansard et al. (2012). Measurements were taken at one meter intervals throughout the water-column to within five meters of bottom. Further details on water mass structure and sampling gear specifications can be found in Majewski et al. (2017) and Stasko et al. (2016).

At capture, fish and other potential prey were sorted and measured to the nearest $0.1 \mathrm{~mm}$. All samples were flash-frozen on board at $-50{ }^{\circ} \mathrm{C}$, then stored at $-30{ }^{\circ} \mathrm{C}$ until shipment to the DFO's Freshwater Institute (Winnipeg, MB, Canada) where they were stored at $-20{ }^{\circ} \mathrm{C}$ in the 
laboratory until analyzed. A subsample of the total catch of Greenland Halibut was selected each year for dietary studies (Table 1). Semi-frozen fish were cut in half lengthwise along the dorsoventral section (sagittal plane which divides the fish between left and right) and the gastrointestinal tract (i.e., stomach and intestine) was removed and either kept frozen or preserved in $4 \%$ formaldehyde solution for gut content analysis. Dorsal muscle tissue for FA analysis was freeze dried (Labconco, model Freezone 18, USA). Samples were vacuum sealed after freeze drying and re-frozen at $-80^{\circ} \mathrm{C}$ until extraction for FA analyses was completed. Dorsal muscle tissue for SI analyses (Table 1,2 ) was oven-dried at $50^{\circ} \mathrm{C}$ and ground to a homogenous powder.

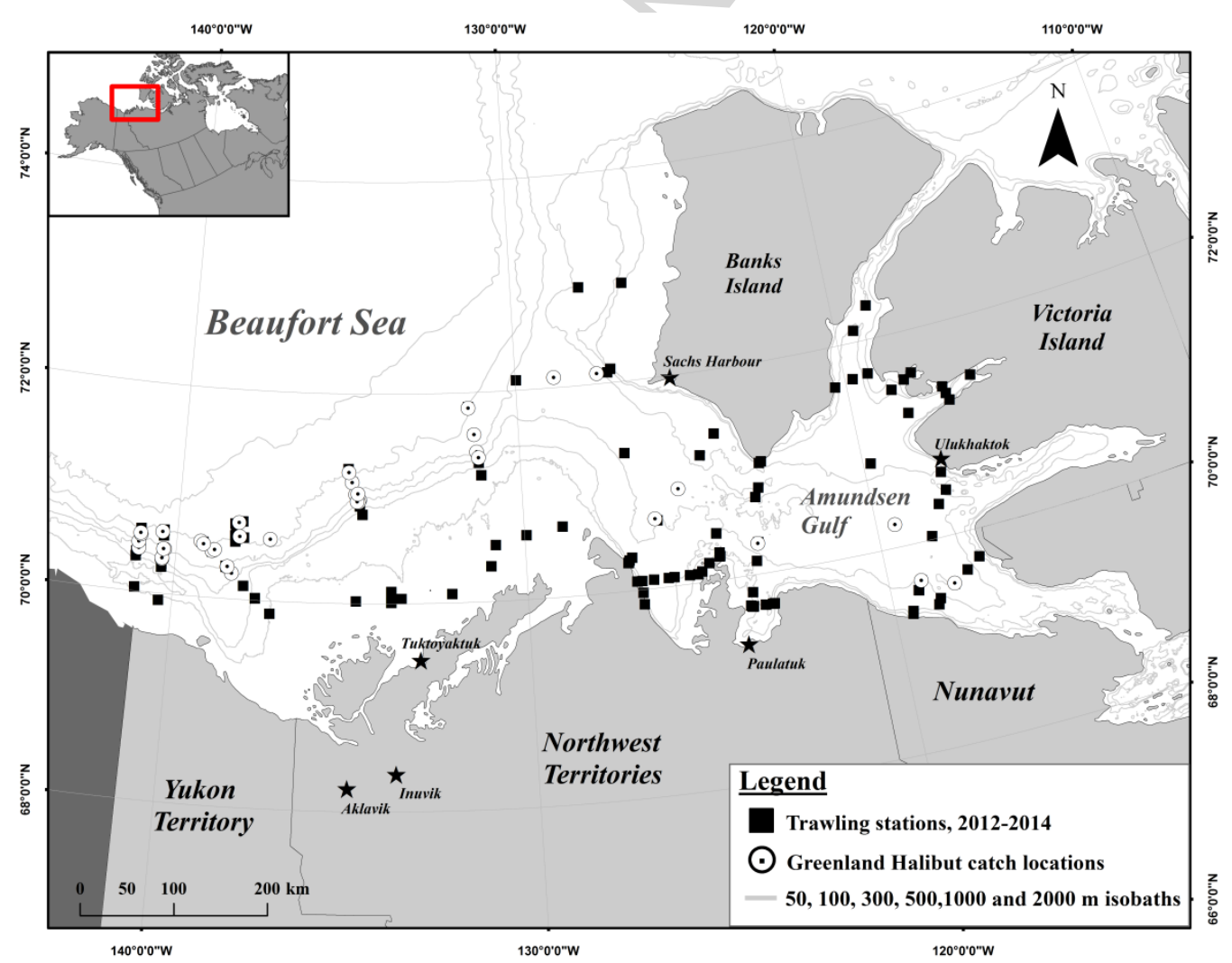

Figure 1: Sampling stations (black squares) visited during the 2012-2014 cruises to the Canadian Beaufort Sea. White circles indicate stations where Greenland Halibut were collected. Isobaths are also indicated. 


\subsection{Diet Analysis}

Variability in the short-term diet was assessed through the analysis of stomach contents. Long-term diet was assessed through analysis of stable isotope ratios $\left(\mathrm{SI}, \delta^{13} \mathrm{C}\right.$ and $\left.\delta^{15} \mathrm{~N}\right)$ and fatty acid (FA) analyses. SI and FA analyses are commonly used to study ecosystem structure and processes, and have been useful in determining energetics and the transfer of organic matter through marine food webs in the Arctic (e.g., Hobson et al. 1995, Iken et al. 2005, Connelly et al. 2014). Delta ${ }^{13} \mathrm{C}$ ratios were used to distinguish benthic food webs from pelagic food webs; $\delta^{13} \mathrm{C}$ ratios tend to be more enriched in benthic/inshore systems (Cherel et al., 2011; DeNiro and Epstein, 1978). The heavy ${ }^{15} \mathrm{~N}$ isotope exhibits enrichment with trophic position at a relatively constant rate, and was therefore used to determine the relative trophic position of Greenland Halibut within the two depth categories (DeNiro and Epstein, 1981; Post, 2002). Finally, most dietary FAs are incorporated into marine animals with little or no modification of the original structure, making them useful as indicators of dietary sources (Budge et al., 2002). For example, specific markers produced de novo by Calanus species de novo (i.e., 20:1(n11, n9) and 22:1(n11, n9)) can be traced through the food web up to predators such as fish, mammals and seabirds (Falk-Petersen et al., 2009, 2007, 1990, 1987), making this marker useful to assess the contribution of pelagic-derived energy to benthic ecosystems (Dahl et al., 2003, Scott et al., 1999).

Diet was analyzed from fishes collected in two depth categories: the upper (300 to $500 \mathrm{~m}$ ) and the lower (750 to $1500 \mathrm{~m}$ ) slope. The cut-off point between these depth categories was established based on significant differences in fish community composition associated with depth and water mass structure as described in Majewski et al. (2017). When possible, the same individual was analyzed for stomach contents, FA and SI. However, depending on laboratory and/or technical constraints some individuals were analyzed using a sub-set of methods (Table 1). 
Table 1: Greenland Halibut catch per depth category (Total catch - all years combined) and subsamples for dietary analysis. SI: stable isotopes. FA: Fatty acids.

\begin{tabular}{lrcclc} 
Habitat & Depth & Stomach contents & SI & FA & Total catch \\
\hline Upper slope & $300-500 \mathrm{~m}$ & 55 & 94 & 45 & 99 \\
Lower slope & $750-1500 \mathrm{~m}$ & 58 & 61 & 59 & 170 \\
\hline & Total & 113 & 155 & 104 & 269
\end{tabular}

\subsubsection{Stomach contents}

All identifiable items were removed from each stomach and taxonomic identification was completed to the lowest practical level, if possible to the species level. Relatively large diet items were measured using electronic calipers (Mitutoyo, model CD-8" PSX, Kawasaki, Japan) whereas the smallest items, such as Copepoda, were identified and measured under a stereomicroscope (Nikon, model SMZ 1000, Japan). Identification of fishes was completed following taxonomical guidelines in Mecklenberg et al., (2002). Prey biomass was assessed using weight-length relationships specific to each taxon (unpublished data for Boreogadus saida, collected during the same cruises in the same locations; Froese et al., (2014) for Liparis and Zoarcidae). The biomass of unrecognizable fishes was estimated using weight-length relationships for Arctic Cod under the assumption that the majority of such remains were Arctic Cod, noted as being the main identifiable fish prey for Greenland Halibut in our study. The total length for digested fish was estimated from the length of the vertebral column and by assuming that the head would have comprised $25 \%$ of the body length (as in B. saida after Boulva, 1979). The biomasses of non-fish taxa were calculated based on published weight factors and equations for particular species (Berestovskii et al., 1989; Richter, 1994; Karnovsky et al., 2002). Results of the stomach contents analyses are presented as the average percentage of the food loads that each taxon constituted, calculated from combined stomach contents of all Greenland Halibut within a particular depth category (Table 2). 


\subsubsection{Fatty acids}

Lipids were extracted from $0.25 \mathrm{~g}$ of freeze-dried muscle tissue (fish) and from entire samples (copepods and amphipods) following a modified Folch method with 2:1 chloroformmethanol containing $0.01 \%$ butylated hydroxytoluene $(\mathrm{v} / \mathrm{v} / \mathrm{w})$ and $0.88 \% \mathrm{NaCl}$, for a final proportion of chloroform:methanol:water of 8:4:7 (Folch et al. 1957). Full details of the procedure for fatty acid analysis can be found in Giraldo et al. (2016). Briefly, the lipid phase was filtered, collected, and dried with anhydrous sodium sulphate and evaporated under nitrogen to obtain the total lipid weight. The extracted lipids were used to prepare the FA methyl esters (FAME) fractions by transesterification with Hilditch reagent ( $0.5 \mathrm{~N} \mathrm{H} 2 \mathrm{SO} 4$ in methanol) (Morrison and Smith 1964). Samples were then analyzed using gas chromatography coupled with a Flame Ionization Detector operating at $350{ }^{\circ} \mathrm{C}$. Peaks were quantified using Agilent Technologies ChemStation software B.03.01 supplied by Agilent Technologies, Mississauga, ON, Canada. FA standards were obtained from Supelco (37 component FAME mix) and Nuchek (54 component mix GLC-463). A total of 73 FAMEs were identified via retention time and known standard mixtures and are reported as percent of total FA. Each FA is described using the shorthand nomenclature of $\mathrm{A}: \mathrm{BnX}$, where A represents the number of carbon atoms, $\mathrm{Bn}$ the number of double bonds, and $\mathrm{X}$ the position of the double bond closest to the terminal methyl group. Calanus-type copepod markers were defined as 20:1(n11, n9) and 22:1(n11, n9) (FalkPetersen et al. 1987).

\subsubsection{Stable isotopes}

SI analyses were completed for Greenland Halibut and their main prey sources collected at the same habitat depths from the same sampling program. Prey selection was based on taxa with the greatest biomass identified in stomachs (Table 2). Ophiuroid brittle stars were included as a representative surface deposit feeder, although they were not recorded in Greenland Halibut 
stomachs in our study. SI methodology and data for prey are available in (Stasko et al., 2017). SI samples were analysed using a Delta Plus continuous flow isotope mass spectrometer (ThermoFinnigan, Bremen, Germany) coupled to a 4010 Elemental Analyzer (Costech International S.p.A., Milan, Italy) at the University of Waterloo Environmental Isotopes Laboratory (Waterloo, ON, Canada). Ratios of heavy to light isotope $\left({ }^{15} \mathrm{~N}:{ }^{14} \mathrm{~N},{ }^{13} \mathrm{C}:{ }^{12} \mathrm{C}\right)$ were expressed in standard $\delta$ notation as parts per thousand (\%o) relative to the international standards atmospheric $\mathrm{N}_{2}$ in air and Vienna Pee Dee Belemnite for N C, respectively (Craig 1957, Mariotti 1983). Mean analytical error was $0.30 \%$ for $\delta^{15} \mathrm{~N}$, and $0.20 \%$ for $\delta^{13} \mathrm{C}$ based on repeated measurements of working laboratory standards cross-calibrated to the international standards. Repeatability based on duplicate measurements of sample material was $0.41 \%$ and $0.36 \%$ for $\delta^{15} \mathrm{~N}$ and $\delta^{13} \mathrm{C}$, respectively.

Table 2: Prey groups and species composition of fish and invertebrates reported in the diet of GH and analyzed for SI from the upper and lower slope (all years combined). Prey groups correspond to those used by the SI mixing model (MixSIAR).

\begin{tabular}{lllc} 
Prey group & \multicolumn{1}{c}{ Species } & Depth category & $n$ \\
\hline Pelagic subsidies & Calanus hyperboreus, Themisto libellula & Upper slope & 29 \\
& & Lower slope & 13 \\
Benthic fish & $\begin{array}{l}\text { Lycodes adolfi, Lycodes pallidus, Lycodes } \\
\text { polaris, Lycodes rossi, Lycodes sagittarius, }\end{array}$ & Upper slope & 103 \\
& Lycodes seminudus, Lycodes squamiventer & Lower slope & 163 \\
Benthopelagic fish & Boreogadus saida, Liparis fabricii, Liparis & Upper slope & 226 \\
& tunicatus & Lower slope & 80 \\
Surface deposit feeders & Ophiacantha bidentata, Ophiopleura borealis & Upper slope & 133 \\
& & Lower slope & 39 \\
& & Total & 786 \\
\hline
\end{tabular}

2.3 Statistical analysis

Feeding strategies based on stomach contents for Greenland Halibut in the upper and lower slope were assessed with a modified Costello method (Amundsen et al., 1996). This 
method offers a two-dimensional, graphical representation of prey-specific abundances and frequency of occurrence of various prey types in the diet. Frequency of occurrence was calculated as follows:

$$
F_{i}[\%]=\left(N_{i} / N\right) * 100
$$

where, $F_{i}$ is a frequency of occurrence of the prey item, $N_{i}$ is the number of stomachs with the $i t h$ prey item and $N$ the total number of stomach analyzed with prey on them. Prey-specific abundance was calculated as follows:

$$
P_{i}[\%]=\left(\sum S_{i} / \sum S_{t i}\right) * 100
$$

where, $P_{i}$ is a prey-specific abundance of prey $i, S_{i}$ is the stomach content (weight) comprised of prey $i, S_{t i}$ is the total stomach content (weight) in only stomachs that contained prey $i$.

Differences in size and \% total lipids content (TL) among years and depth categories were analyzed using the non-parametric Kruskal-Wallis test. MANOVA was used to compare main FA $(>5 \%)$ between individuals collected in the upper and lower slope. A total of 25 dietary FA (Iverson et al. 2004) were identified with mean percentages above $0.1 \%$ of the total FA, and collectively represented $83-98 \%$ of the total FA. Identified FA were used to compare Greenland Halibut FA signatures from the upper and lower slope to the FA profiles of potential fish prey (based on results from stomach contents). FA from prey fish were taken from Giraldo et al. (2016). Discrimination among prey groups was evaluated using linear discriminant analysis (LDA). The prediction function of the LDA was then used to determine the probability of Greenland Halibut belonging to one of the potential prey groups. Percentage values of FA were log-transformed into ratios prior to LDA by first renormalizing the values for the 25 FA over 100 $\%$ and then dividing the value for each of the other fatty acids by the value for 18:0 (reference FA, Budge et al. 2002). The resulting ratios were then log-transformed and used in the analyses. 
As the size of the fish is often related to $\delta^{15} \mathrm{~N}$ trophic enrichment (Romanuk et al., 2011), the relationships between SI data and total length were examined using linear regression. Mean $\delta^{15} \mathrm{~N}$ and $\delta^{13} \mathrm{C}$ were calculated for each depth and year group to compare the average trophic positions of each group. The range of $\delta^{15} \mathrm{~N}$ values observed within each depth and year group was used to estimate the range of trophic levels occupied by individuals in the group, whereas the range of $\delta^{13} \mathrm{C}$ was used to estimate the breadth of dietary carbon sources exploited by each group (Bearhop et al., 2004). The MixSIAR Bayesian isotope mixing model (Stock and Semmens, 2013) was used to determine probability distributions for the proportion of pelagic/benthic sources in the diet of Greenland Halibut. Following recommendations in Phillips et al. (2014) for meeting the assumptions of the mixing model analysis, taxa with SI values that were not significantly different, but which shared the same habitat or were within the same trophic guild were combined into prey groups (see Table 2). Diet-tissue discrimination factors were set to 0.40 \pm 1.20 for $\Delta^{13} \mathrm{C}$ and $2.30 \pm 1.61$ for $\Delta^{15} \mathrm{~N}$ as suggested by Moore and Semmens (2008) for omnivorous fish and by Hussey et al. (2014) for $\Delta^{15} \mathrm{~N}$ of Greenland Halibut from the Canadian Arctic. The model was run under the "long" setting with the following parameters: $3 * 10^{5}$ chain length, burn-in 200.000 and thin number 100 for three parallel MCMC chains. Depth category (i.e., upper and lower slope) was set as a random effect, resulting in three dietary estimates: upper and lower slope, and overall population. Convergence was assessed using the default MixSIAR diagnostic Gelman-Rubin and Geweke tests. For every MixSIAR dietary estimate, mean contributions, standard deviations and $2.5 \%$ and $95.7 \%$ credible intervals (CI) are reported.

All statistical procedures were conducted in R ver. 3.3.2 (R Core Team 2012).

\section{Results}

3.1. Habitat and maturity 
In total, 269 Greenland Halibut were captured during the three field seasons. Of the 138 stations sampled, Greenland Halibut were captured at 38 locations (Figure 1). Catch depths ranged from 343 to $1500 \mathrm{~m}$ depth, coinciding with the presence of the Atlantic water mass, at shallower locations, and the Arctic water mass at deeper stations. Averaged bottom temperatures at catch locations, where available, ranged from -0.17 to $0.60{ }^{\circ} \mathrm{C}$, and average bottom salinities ranged from 34.73 to 34.90 . Total length of Greenland Halibut for the overall catch varied from 337 to $779 \mathrm{~mm}$ with an overall mean of $502.24 \pm 63.58 \mathrm{~mm}$. No differences in size were found among years (Kruskal-Wallis chi-squared $=2.92, \mathrm{df}=2, \mathrm{p}$-value $=0.23$ ). When analyzed by depth (pooled across all years), individuals were significantly larger (median $=511 \mathrm{~mm}$ ) on the lower slope (750 to $1500 \mathrm{~m}$ ) than on the upper slope (300 to $500 \mathrm{~m}$, median fish length $478 \mathrm{~mm}$ ) (Kruskal-Wallis chi-squared $=6.76, \mathrm{df}=1, \mathrm{p}$-value $<0.001)$

3.2 Stomach contents

The percentage of empty stomachs varied: $57 \%$ in 2012, $38 \%$ in 2013 and $5 \%$ in 2014. The diet of Greenland Halibut consisted of 18 food taxa that included 13 defined species and 5 broader taxa categories (Table 3 ). In all years and depth zones, the diet of Greenland Halibut was dominated by a high percentage of fish (86 - $99 \%$ of total prey biomass). Greenland Halibut collected in the upper slope fed predominantly on Arctic Cod, with Zoarcidae (eelpouts) and other unidentified fishes also being important. Less important were crustaceans and polychaetes. The diet of individuals collected in the lower-slope was dominated by Liparis fabricii (Gelatinous Seasnail) (32 - $62 \%$ of total prey biomass), with Zoarcidae, unidentified fishes and Arctic Cod also contributing to the diet. The demersal mysid Boreomysis arctica and multiple eggs (likely fish eggs of $\sim 3.4 \mathrm{~mm}$ in diameter,) were found in stomachs of individuals from the lower slope only. 
Table 3: Diet composition (percentage of weight) of Greenland Halibut collected from 2012 to 2014 on the upper slope $(300-500 \mathrm{~m})$ and lower slope $(750-1500 \mathrm{~m})$.

\begin{tabular}{|c|c|c|c|c|c|c|}
\hline \multirow[b]{2}{*}{ Taxon } & \multirow[b]{2}{*}{$\begin{array}{c}\text { Habitat } \\
\text { preference }\end{array}$} & \multicolumn{2}{|c|}{2012} & \multicolumn{2}{|c|}{2013} & \multirow{2}{*}{$\begin{array}{l}2014 \\
\text { upper }\end{array}$} \\
\hline & & upper & lower & upper & lower & \\
\hline Boreogadus saida & benthopelagic & 94 & 17 & 50 & 4 & 75 \\
\hline Liparis fabricii & benthopelagic & & 62 & & 32 & \\
\hline Zoarcidae & demersal & 5 & & 27 & 17 & 13 \\
\hline Unidentified fishes & unknown & & 15 & 19 & 28 & 9 \\
\hline Eggs & bathypelagic & & $<1$ & & 6 & \\
\hline Fishes total & & 99 & 94 & 90 & 86 & 97 \\
\hline Boreomysis arctica & demersal & $<1$ & & & 4 & 1 \\
\hline Ampeliscidae & benthic & & & & 4 & \\
\hline Themisto libellula & pelagic & & 1 & & & $<1$ \\
\hline Themisto abyssorum & pelagic & & & & & $<1$ \\
\hline Meganyctiphanes norvegica & pelagic & & & & & \\
\hline Isopoda ndet. & benthic & & & $<1$ & & \\
\hline Rhachotropis aculeata & benthic & & $<1$ & & & \\
\hline Thysanoessa inermis & pelagic & & $<1$ & & & \\
\hline Sabinea septemcarinata & demersal & & & & & 1 \\
\hline Gammaracanthus loricatus & pelagic & & & & & $<1$ \\
\hline Gammarellus homari & pelagic & & & & & $<1$ \\
\hline Calanus hyperboreous & pelagic & & & & & $<1$ \\
\hline Crustaceans to & & $<1$ & 6 & $<1$ & 8 & 3 \\
\hline Polychaeta & benthic & & & 3 & 6 & \\
\hline Stomachs analysed/empty & & $54 / 31$ & & $40 / 15$ & & $19 / 01$ \\
\hline
\end{tabular}

Analysis of feeding strategies using the modified Costello method showed that Greenland Halibut had a relatively high between-phenotype contribution (BPC) to the feeding niche width, indicating variable resource utilization among individuals (Figure 2). There was a rather high degree of specialization observed in both the upper and lower slope (as indicated by prey items in the upper left corner), with some rare taxa present as well (lower left corner). 

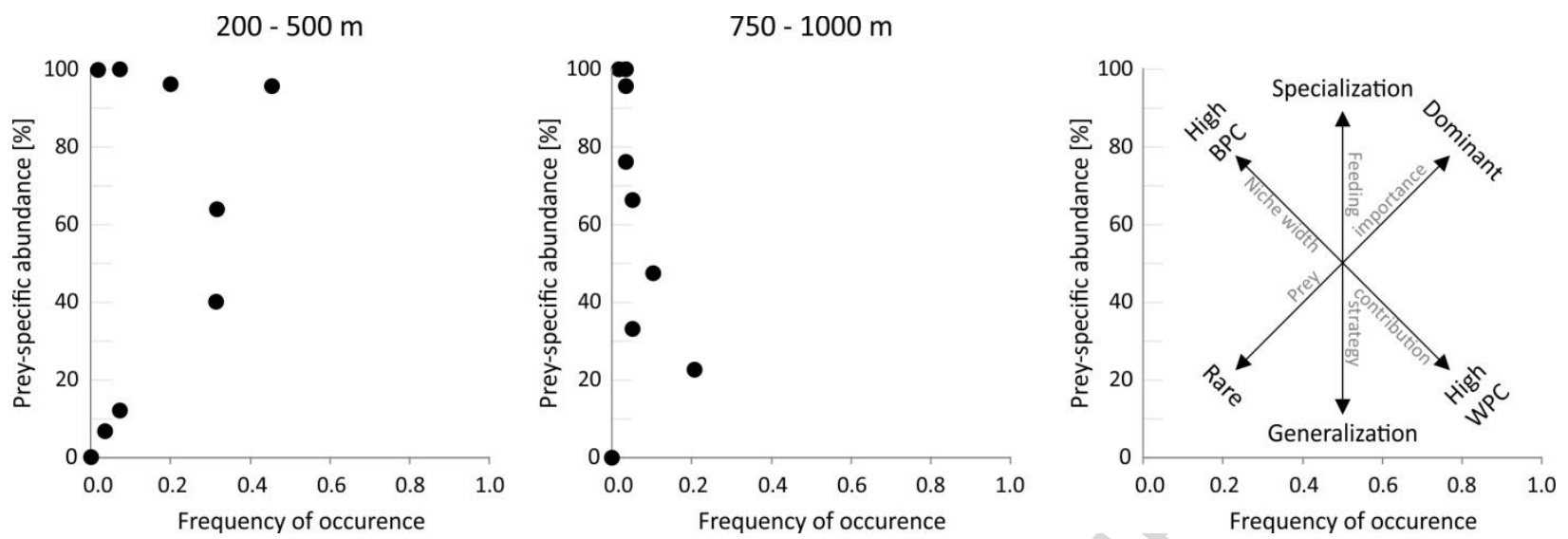

Figure 2: Feeding strategy diagram based on stomach contents analysis: prey-specific abundance plotted against frequency of occurrence of prey in the diet of Greenland Halibut in the upper (left) and lower (middle) slope. The points represent different prey types (Table 3). The explanatory diagram as proposed by Amundsen et al. (1996) is presented on the right for interpretation. BPC: between-phenotype contribution. WPC: within-phenotype contribution.

3.2 Lipids and fatty acids

Mean \pm SD \% total lipid content in Greenland Halibut was high for all individuals (32.64 $\pm 12.65 \%$ dry weight) with no significant differences between individuals collected on the upper and lower slope. Total lipids content varied among years (Kruskal-Wallis chi-squared $=24.33$, df $=2$, p-value < 0.001); individuals captured in 2014 had significantly lower \% TL (18.89 \pm 10.30 $\%)$ compared to individuals captured in either 2012 (32.58 $\pm 8.96 \%$, pairwise comparisons using Tukey and Kramer (Nemenyi) test, p-value < 0.001) or $2013(37.88 \pm 14.09 \%$, pairwise comparisons using Tukey and Kramer (Nemenyi) test, p-value <0.001). Overall, 37 FA accounted for $96-100 \%$ of the total FA identified. Among these 37 FA, 16:0, 16:1n7, 18:1(n7, n9), 20:1n9, 20:5n3, 22:1n11 and 22:6n3 had values > $5 \%$ (accounting for $82-86 \%$ of total FA) and were used to compare spatial (upper and lower slope) and inter-annual variability in Greenland Halibut. Significant differences were found between the two depth categories (pooled across years) and among years (see summary of results in Table 4). When dietary FA of Greenland Halibut (Table 5) were compared to the FA profiles of potential fish prey, the benthopelagic fishes Arctic Cod and Kelp snailfish L. tunicatus, and benthic fishes (Zoarcidae 
Canadian eelpout L. polaris, Adolf's eelpout L. adolfi and Longear eelpout L. seminudus) were well separated by the two discriminant functions (posterior probability after cross-validation of 97.3\%) (Figure 3a). The first discriminant function (LD1, 66.7\% of the variance) separated Arctic Cod from benthic fishes. Coefficients of LD1 were primarily defined by high values of 20:4n6 (benthic marker) and low values of 20:5n3. The second discriminant function (LD2, 33.2\% of the variance) separated other benthopelagic fish from Arctic Cod and benthic fishes. Coefficients of LD2 were primarily defined by high values of 18:1n7, 14:0, 22:6n3 and low values of 16:0 (Figure 3b). Using the prediction function of the LDA, Greenland Halibut were attributed to the class "Arctic Cod" at 100\% regardless of the sampling year or depth.

Table 4: Results of MANOVA on the variation of main fatty acids (FA $>5 \%$ ) in Greenland Halibut among sampling years (2012-2014) and depths categories (upper and lower slope). Highly significant FA $(p<0.001)$ are indicated in bold.

\begin{tabular}{|c|c|c|c|c|c|c|}
\hline Variable & Wilks $\lambda$ & F value & $n$ Df & d Df & $p$-value & Univariately significant FA (anova) \\
\hline Depth & 0.58 & 8.16 & 8 & 92 & $<0.001$ & $16: 1 n 7,18: 1 n 7,20: 1 n 9,20: 5 n 3,22: 6 n 3$ \\
\hline Year & 0.31 & 9.12 & 16 & 184 & $<0.001$ & $\begin{array}{l}\text { 16:0, 16:1n7, 18:1n-9, 18:1n7, 20:5n3, } \\
22: 6 n 3\end{array}$ \\
\hline
\end{tabular}

*F Statistic for Wilks' Lambda test. n Df : number of degrees of freedom in the model. d DF: number of degrees of freedom associated with the model errors. 

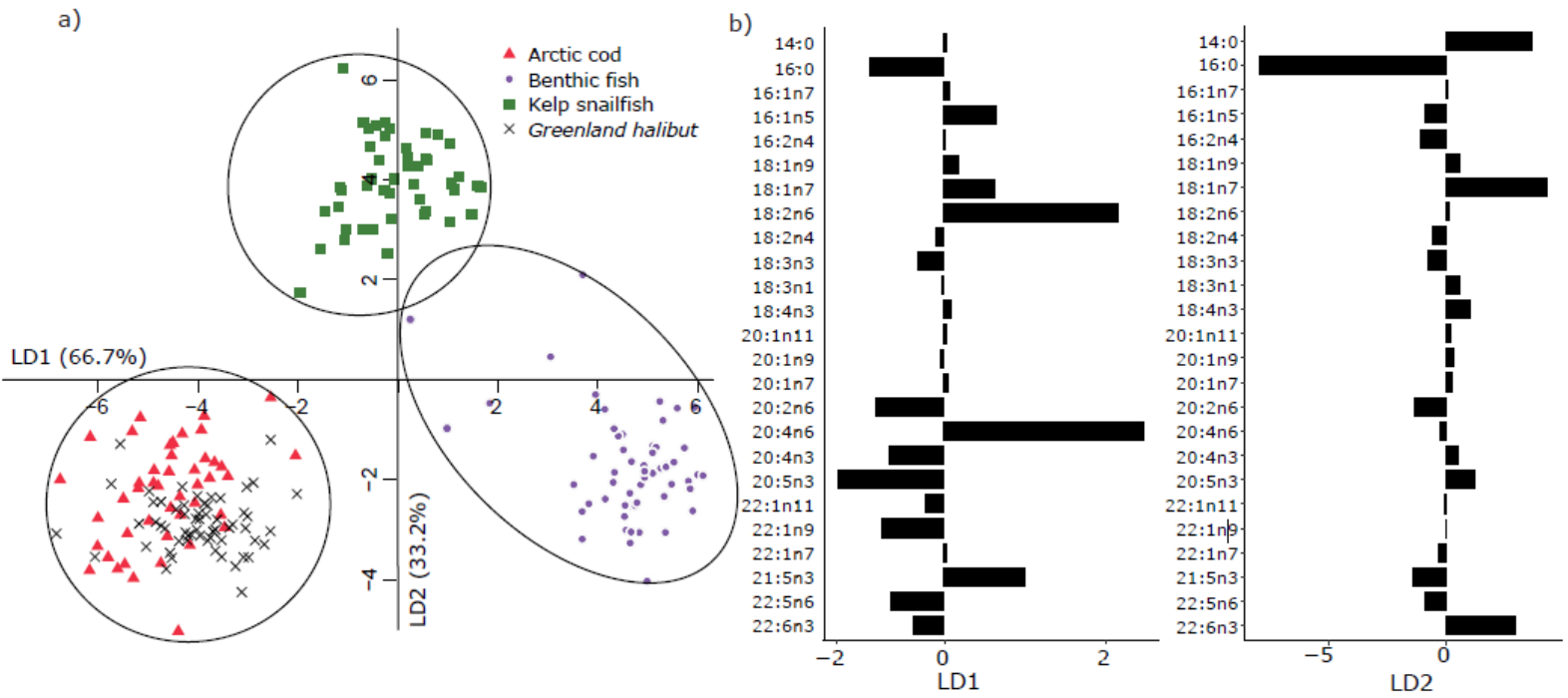

Figure 3: (a) Linear discriminant analysis of the main fish prey: Benthopelagic fishes: Arctic Cod, Kelp snailfish; Benthic fish species (Zoarcids) as reported from Giraldo et al. (2016) and prediction class for Greenland Halibut. (b) Contribution of the 25 dietary FA used in the analysis to discriminant functions LD1and LD2. 
Table 5: Lipids and fatty acids (FA) in Greenland Halibut. Values are reported as mean \pm standard deviation by factor (depth or year). The FA listed in this table correspond to the dietary FA used in the linear discriminant analysis (following transformation as explained in the Methods). Main FA (> $5 \%$ ) used in MANOVA are in bold.

\begin{tabular}{|c|c|c|c|c|c|}
\hline & \multicolumn{2}{|c|}{ Depth categories } & \multicolumn{3}{|c|}{ Year } \\
\hline & $\begin{array}{l}\text { Lower slope } \\
\qquad(n=59)\end{array}$ & $\begin{array}{l}\text { Upper slope } \\
\quad(n=45)\end{array}$ & $\begin{array}{c}2012 \\
(n=52)\end{array}$ & $\begin{array}{c}2013 \\
(n=34)\end{array}$ & $\begin{array}{c}2014 \\
(n=18)\end{array}$ \\
\hline $\begin{array}{l}\text { Lipid content (\%) } \\
\text { Saturated FA (\%) }\end{array}$ & $34.66 \pm 9.83$ & $30.23 \pm 15.13$ & $33.33 \pm 7.63$ & $40.59 \pm 14.04$ & $17.95 \pm 9.78$ \\
\hline $14: 0$ & $3.45 \pm 0.47$ & $3.19 \pm 0.33$ & $3.50 \pm 0.42$ & $3.26 \pm 0.40$ & $3.04 \pm 0.32$ \\
\hline 16:0 & $12.42 \pm 0.84$ & $12.64 \pm 1.06$ & $12.47 \pm 0.75$ & $12.28 \pm 0.86$ & $13.12 \pm 1.32$ \\
\hline $18: 0$ & $2.33 \pm 0.24$ & $2.41 \pm 0.27$ & $2.32 \pm 0.23$ & $2.38 \pm 0.28$ & $2.46 \pm 0.28$ \\
\hline \multicolumn{6}{|l|}{ Monosaturated FA (\%) } \\
\hline $16: 1 n 7$ & $14.55 \pm 1.68$ & $13.82 \pm 1.58$ & $14.32 \pm 1.41$ & $14.73 \pm 1.82$ & $13.05 \pm 1.56$ \\
\hline 18:1n9 & $17.30 \pm 2.63$ & $16.97 \pm 2.18$ & $16.39 \pm 2.28$ & $18.81 \pm 2.14$ & $16.27 \pm 1.89$ \\
\hline $18: 1 n 7$ & $4.98 \pm 0.56$ & $4.76 \pm 0.39$ & $4.79 \pm 0.40$ & $5.16 \pm 0.59$ & $4.66 \pm 0.34$ \\
\hline $20: \ln 11$ & $0.99 \pm 0.31$ & $0.94 \pm 0.21$ & $0.92 \pm 0.23$ & $1.02 \pm 0.30$ & $0.98 \pm 0.30$ \\
\hline $20: 1 n 9$ & $12.59 \pm 2.03$ & $11.28 \pm 1.55$ & $12.29 \pm 1.74$ & $12.18 \pm 2.04$ & $10.96 \pm 2.04$ \\
\hline $20: \ln 7$ & $1.18 \pm 0.17$ & $1.17 \pm 0.20$ & $1.17 \pm 0.16$ & $1.23 \pm 0.15$ & $1.09 \pm 0.25$ \\
\hline $18: 3 n 1$ & $0.10 \pm 0.02$ & $0.10 \pm 0.01$ & $0.09 \pm 0.02$ & $0.11 \pm 0.01$ & $0.10 \pm 0.01$ \\
\hline 22:1n11 & $6.83 \pm 1.79$ & $6.56 \pm 2.04$ & $6.91 \pm 1.51$ & $6.66 \pm 1.93$ & $6.26 \pm 2.72$ \\
\hline $22: \ln 9$ & $1.89 \pm 0.31$ & $1.78 \pm 0.31$ & $1.91 \pm 0.25$ & $1.86 \pm 0.32$ & $1.64 \pm 0.39$ \\
\hline $22: \ln 7$ & $0.31 \pm 0.08$ & $0.36 \pm 0.09$ & $0.32 \pm 0.09$ & $0.36 \pm 0.08$ & $0.34 \pm 0.10$ \\
\hline \multicolumn{6}{|l|}{ Polyunsaturated FA (\%) } \\
\hline $16: 2 \mathrm{n} 4$ & $0.30 \pm 0.05$ & $0.29 \pm 0.05$ & $0.31 \pm 0.05$ & $0.29 \pm 0.06$ & $0.26 \pm 0.04$ \\
\hline $18: 2 \mathrm{n} 6$ & $0.67 \pm 0.13$ & $0.60 \pm 0.10$ & $0.66 \pm 0.12$ & $0.63 \pm 0.14$ & $0.60 \pm 0.08$ \\
\hline $18: 2 \mathrm{n} 4$ & $0.09 \pm 0.01$ & $0.09 \pm 0.01$ & $0.09 \pm 0.01$ & $0.09 \pm 0.01$ & $0.08 \pm 0.01$ \\
\hline $18: 3 n 3$ & $0.21 \pm 0.05$ & $0.21 \pm 0.04$ & $0.21 \pm 0.05$ & $0.21 \pm 0.05$ & $0.20 \pm 0.05$ \\
\hline $18: 4 n 3$ & $0.42 \pm 0.24$ & $0.41 \pm 0.17$ & $0.44 \pm 0.21$ & $0.40 \pm 0.24$ & $0.37 \pm 0.11$ \\
\hline $20: 2 \mathrm{n} 6$ & $0.24 \pm 0.03$ & $0.22 \pm 0.03$ & $0.24 \pm 0.03$ & $0.23 \pm 0.04$ & $0.21 \pm 0.03$ \\
\hline $20: 4 n 6$ & $0.58 \pm 0.15$ & $0.54 \pm 0.18$ & $0.58 \pm 0.13$ & $0.50 \pm 0.15$ & $0.65 \pm 0.23$ \\
\hline $20: 4 n 3$ & $0.24 \pm 0.06$ & $0.27 \pm 0.04$ & $0.25 \pm 0.05$ & $0.25 \pm 0.06$ & $0.26 \pm 0.05$ \\
\hline $20: 5 n 3$ & $4.72 \pm 0.81$ & $5.49 \pm 1.09$ & $5.15 \pm 0.70$ & $4.47 \pm 0.80$ & $5.87 \pm 1.45$ \\
\hline $21: 5 n 3$ & $0.12 \pm 0.03$ & $0.13 \pm 0.02$ & $0.13 \pm 0.03$ & $0.13 \pm 0.03$ & $0.13 \pm 0.03$ \\
\hline $22: 5 n 3$ & $1.01 \pm 0.22$ & $1.14 \pm 0.14$ & $1.10 \pm 0.19$ & $0.98 \pm 0.19$ & $1.14 \pm 0.18$ \\
\hline 22:6n3 & $6.20 \pm 1.53$ & $8.03 \pm 3.07$ & $6.78 \pm 1.26$ & $5.80 \pm 1.94$ & $9.84 \pm 3.72$ \\
\hline Total & $98.53 \pm 3.39$ & $97.97 \pm 0.47$ & $97.92 \pm 1.78$ & $98.9 \pm 3.89$ & $98.2 \pm 0.46$ \\
\hline
\end{tabular}

\subsection{Stable Isotopes}

Neither $\delta^{15} \mathrm{~N}$ nor $\delta^{13} \mathrm{C}$ were significantly related to standard length in Greenland Halibut for any group, whether the data were split by year or depth category. As a result, species size adjustments were not undertaken. Within each habitat/year grouping, Greenland Halibut occupied a narrow range of trophic positions (Nitrogen range within groups spanned 2.97 to $3.71 \%$ ), 
approximating a single trophic level (Post 2002). In contrast, most groups displayed greater variability in resource use as measured by carbon ranges (Table 6).

Table 6: Metrics of isotopic trophic variability for Greenland Halibut divided into groups by depth and by year. Trophic variability metrics include carbon $\left(\delta^{13} \mathrm{C}\right)$ and nitrogen $\left(\delta^{15} \mathrm{~N}\right)$ ranges.

\begin{tabular}{rr|c|cccc}
\hline \multicolumn{2}{c|}{ Group } & $\boldsymbol{n}$ & Mean $\boldsymbol{\delta}^{\mathbf{1 3}} \mathbf{C}$ & Mean $\boldsymbol{\delta}^{\mathbf{1 5}} \mathbf{N}$ & $\boldsymbol{\delta}^{\mathbf{1 3}} \mathbf{C}$ range & $\boldsymbol{\delta}^{\mathbf{1 5}} \mathbf{N}$ range \\
\hline \multirow{2}{*}{ Depth } & Upper slope & 61 & -22.47 & 16.03 & 6.97 & 3.18 \\
& Lower slope & 94 & -22.70 & 16.31 & 4.86 & 3.71 \\
\hline \multirow{2}{*}{ Year } & 2012 & 104 & -22.32 & 16.01 & 6.97 & 2.97 \\
& 2013 & 34 & -23.22 & 16.62 & 2.87 & 3.34 \\
& 2014 & 17 & -23.18 & 16.51 & 3.27 & 2.97 \\
\hline
\end{tabular}

MixSIAR analyses of SI data (Figure 4) showed that Greenland Halibut consumed mainly benthopelagic fish (mean contribution of $34 \% \pm 16 \%$ ) with surface deposit feeders also being of great importance $(31 \% \pm 11 \%)$. Pelagic subsidies and benthic fish represented $20 \% \pm 11 \%$ and $14 \% \pm 10 \%$ of the food source, respectively. Similar trends were observed when data were split by depth categories (i.e., lower and upper slope). Benthopelagic fish (43\% $\pm 13 \%$ ) and surface deposit feeders $(0.37 \pm 5 \%)$ were particularly important in the lower slope, collectively representing $>80 \%$ of the diet. In contrast, individuals in the upper slope exhibited more generalist feeding, with all four sources contributing between 18 - $32 \%$ to the diet. 


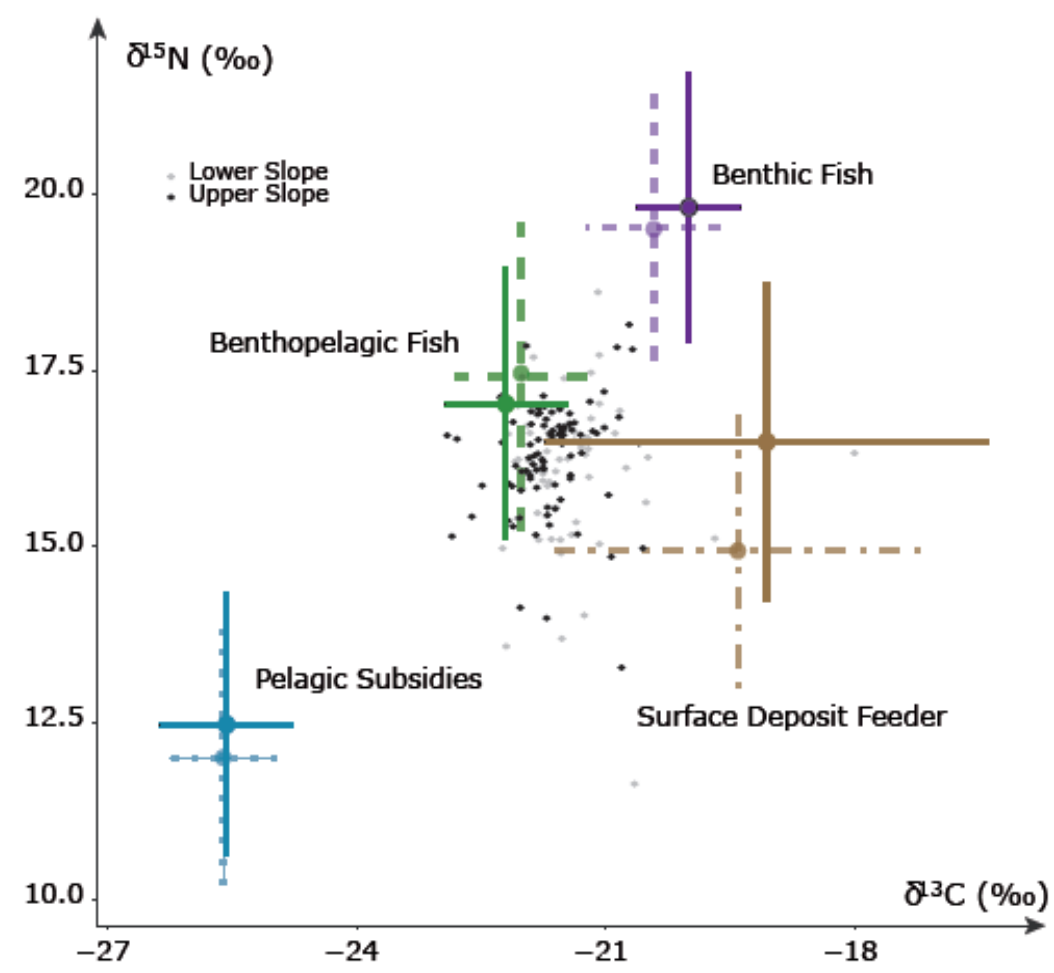

1Benthic Fish 2.Benthopelagic Fish 3Pelagic Subsidies 4Surface Deposit Feeders

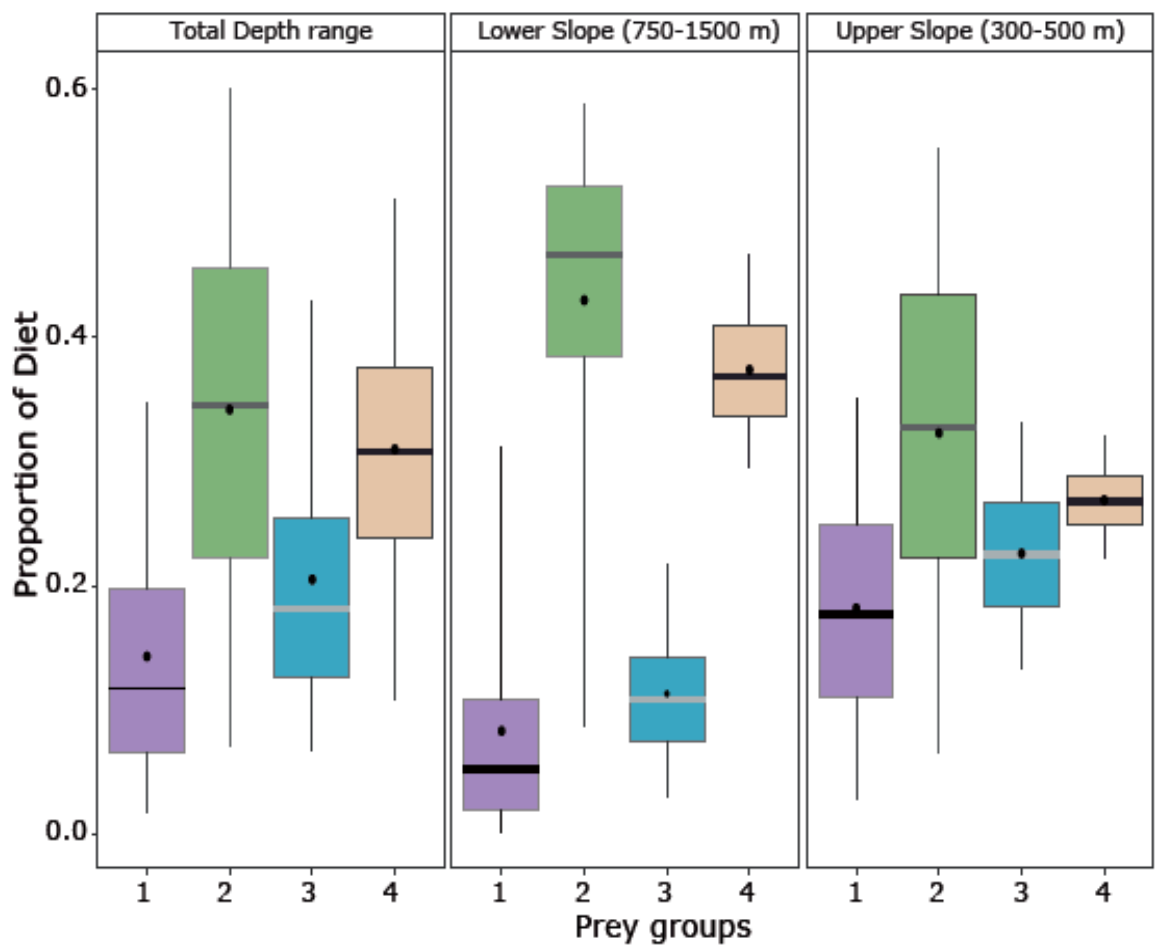

Figure 4: Diet of Greenland Halibut as inferred from results of MixSIAR analysis. (Top) SI biplot displaying individual SI values for all Greenland Halibut (black and grey dots for upper and lower slope respectively) together with average SI values for prey sources (e.g., "Benthic Fish"; colored dots). Dotted and solid lines indicate values for prey sources on the lower and upper slope respectively. The latter have been adjusted by diet-tissue discrimination factors means and are associated with error bars indicating \pm SD resulting from combined source and discrimination uncertainty. (Bottom) 
Proportional contributions of the different sources to the diet of the overall Greenland Halibut population; 1: Benthic fish (Zoarcidae Lycodes sp), 2: Benthopelagic fish (Liparis sp, B. saida, T. pingelli), 3: Pelagic subsidies (C. hyperboreus, T. libellula), 4: Surface deposit feeders (Brittle stars). 


\section{Discussion}

4.1 Pelagic-derived energy in the diet of Greenland Halibut

The influence of pelagic prey and/or pelagic-derived energy to the diet of Greenland Halibut was confirmed using a combination of the short-term (pelagic species found in the stomach contents) and longer-term diet indicators (large $\delta^{13} \mathrm{C}$ range within groups; Calanus-type markers). Whereas it was previously thought that feeding on pelagic sources was restricted to young individuals (mainly around $300 \mathrm{~mm}$ (Jørgensen 1997a)), we found evidence of pelagic prey in the stomachs of larger individuals as well (up to $780 \mathrm{~mm}$ ). It thus appears that pelagic-derived energy remains an important source to Greenland Halibut even into adulthood. Calanus-type markers (e.g., 20:1n9) in Greenland Halibut dominated FA signatures, and represented more than $20 \%$ of total FA. Values of these markers were within the range of percentages reported for pelagic species such as Arctic Cod and Capelin Mallotus villosus (Loseto et al. 2009, Petursdottir et al. 2012). Calanus-type markers were also at least three to seven times higher in Greeland Halibut than in other Arctic benthic fish species (Giraldo et al. 2016), indicating a strong contribution of pelagicderived sources to the diet of Greenland Halibut.

Diverse non-exclusive mechanisms could explain the high Calanus-type marker values in a demersal species: (1) accumulation through the consumption of herbivorous and/or carnivorous benthic/benthopelagic prey (indirect link to pelagic carbon sources); (2) scavenging on pelagic prey that reaches the sea floor; (3) direct feeding on pelagic prey either by vertical migration of Greenland Halibut or seasonal/ontogenetic vertical migration of pelagic prey into greater depths. Stomach contents and SI analysis support the first mechanism as Arctic Cod and zoarcids are important prey for Greenland Halibut. Arctic Cod can be found in demersal habitats throughout the study area (upper and lower slope), and they generally feed on pelagic prey sources including Calanus copepods and Themisto amphipods (Majewski et al., 2016b; Walkusz et al., 2013). 
Zoarcids (e.g., Lycodes spp.) are found at greater depths (lower slope) and are also characterized by a high content of Calanus-type markers through consumption of benthic prey that feed on copepods (Giraldo et al., 2016). Therefore, feeding on Arctic Cod and/or zoarcids would relay the pelagic signal up the food chain. FA results are supported by high $\delta^{15} \mathrm{~N}$ values (and narrow nitrogen range) in Greenland Halibut, which are characteristic of a piscivorous species. The large range in carbon isotopic ratios indicates contributions of both benthic and pelagic sources.

High occurrences of fish heads in stomachs in previous studies conducted in the northAtlantic have concluded that scavenging behaviour might be important for Greenland Halibut (Bergstad and Bjelland 1998). The importance of scavenging may be specific to environments where Capelin (a semelparous species) dominates the available prey (via mass die-offs occur following spawning events, Vilhjálmsson 1994), or to regions where commercial fishing vessels discard fish remains (heads and viscera) (Solmundsson 2007). In this study, scavenging behaviour on pelagic prey seems unlikely given that there are no commercial fisheries in the CBS, most fish prey were found whole (or as full vertebral columns) and Capelin in the region are typically captured outside of the depth range of Greenland Halibut (McNicholl et al., 2016).

Direct feeding on pelagic prey is also supported by stomach content data, i.e., the presence of benthopelagic fish (Arctic Cod) and pelagic crustaceans (e.g., T. libellula, $M$. norvegica). It remains unclear if predation on pelagic prey was the result of active migration of Greenland Halibut into the water column and/or the result of vertical migrations of pelagic prey. Some species such as $M$. norvegica are known to remain in deeper waters (100-500 m depth) during the day and to move into shallower waters at night (Kaartvedt, 2010; Einarsson 1945). Similarly, it has been suggested that Arctic Cod could settle to the sea floor to avoid predation from diving marine mammals during the summer (Geoffroy et al., 2016)

4.2 Spatial and temporal trophic variability 
From the analysis of the feeding strategies (modified Costello method, Amundsen et al., 1996) Greenland Halibut in the CBS have a relatively specialized diet (prevalence of a few fish species suggesting narrow diet niche), and display a consistent pattern over time. Results are consistent with previous studies based on stomach contents that show that the diet of Greenland Halibut can be dominated by one prey type (e.g., Capelin, Bowering and Lilly (1992); squid of the genus Gonatus, Dawe et al. (1998) or Atlantic Cod Gadus morhua, Vollen et al. (2004)) depending on prey abundances in a given habitat. In this study, Greenland Halibut relied heavily on Arctic Cod in the upper slope habitats (94\% of total prey biomass) whereas in deeper habitats it fed on L. fabricii, zoarcids and to lesser extent on Arctic Cod. Comparison with prey distributions from 2012 supports the hypothesis that the diet of Greenland Halibut mirrors changes in prey availability over time (years) and space (Majewski et al., 2017). Arctic Cod biomass on the Beaufort Sea Shelf was concentrated on the upper slope and was much less abundant in the deeper habitats whereas zoarcids were more abundant in deeper waters (Majewski et al., 2017).

In contrast to the spatial variability in diet suggested by stomach contents, the use of biomarkers (SI, FA) showed no major differences in the diet of Greenland Halibut (either among years or sampling depths). Biomarkers integrate diet over a longer time scale ( months) than stomach contents, and are useful for identification of major trophic pathways and sources (Giraldo et al., 2017). Periods of distinctly different vertical and horizontal (seasonal) migration activity on both short (hours-days) and long (days-months) time scales have been identified in Greenland Halibut (Boje et al., 2014; Vollen and Albert, 2008). Such migrations are thought to be linked to foraging activity; thus, when diet is integrated over several weeks to months, local/immediate variability in the diet is dampened, which result in no distinguishable changes over time and/or space, if no major changes have occurred in the environment. 
4.3 Role of Greenland Halibut in the CBS food web

Fishes, and particularly top predators, can be used as integrators of environmental change and ecosystem dynamics (Davoren and Montevecchi, 2003; Giraldo et al., 2017). Furthermore, highly mobile predatory fish such as Greenland Halibut can link spatially-segregated trophic networks, thus influencing ecosystem structure and increasing stability (McCann et al., 2005). In the CBS, the feeding patterns of Greenland Halibut indicate diet similarity between individuals from the upper and lower slope environments. The major contribution of pelagic-derived energy to Greenland halibut diets suggests that the species plays a major role in the coupling of pelagic and benthic energy pathways in the CBS. Previous research along the CBS slope based on SI and the size-based trophic structure of demersal fish communities indicated that the lower slope and upper slope habitats support a relatively high biomass of large-bodied fish, Greenland Halibut in particular (Stasko et al. 2016). The authors hypothesized that the high biomass of large-bodied relative to small-bodied fishes in deeper habitats was supported by Greenland Halibut that were able to obtain dietary subsidies from the pelagic zone (Stasko et al. 2016). Our dietary analyses on fish from the same sampling program confirm this hypothesis.

Sea-ice loss in the Arctic is significantly altering the organic matter pathways that support marine fish communities (McLaughlin and Carmack 2010). Warming sea-surface temperatures and longer ice-free periods are expected to result in increased primary production, which in turn is expected to favour increasingly productive pelagic communities that will retain a larger portion of newly-produced organic matter in the pelagic zone (McLaughlin and Carmack 2010, Wassmann and Reigstad 2011). In such a scenario, Greenland Halibut will be an important pelagic-benthic coupler, delivering pelagic-derived nutrients to demersal communities through active biological transport (e.g., Trueman et al. 2014) if they perform vertical foraging migrations as suggested by stomach contents in this study. On the other hand, Arctic Cod, which were the 
most important prey for CBS Greenland Halibut, are associated with sea ice during their larval and juvenile stages (Bouchard \& Fortier 2011, Hop \& Gjøsæter 2013). Changes in the abundance of Arctic Cod in response to a warmer Arctic are expected to have important cascading effects on Arctic marine food-webs (Bouchard et al. 2017) including Greenland Halibut. For example, Arctic Cod abundances in the CBS were low in 2014 (Majewski et al. 2016a), presumably because of low recruitment linked to early ice-off over the previous years (Bouchard et al. 2017). Although stomach contents and trophic markers still indicated a high contribution of Arctic Cod to Greenland Halibut diet in 2014, lipid content in Greenland Halibut was significantly lower in 2014. It is plausible that lower lipid content in Greenland Halibut was linked to the lower abundances of Arctic Cod, either through lower feeding rates or higher energy expenditure in seeking prey (e.g., more frequent vertical migrations). Compared to other benthic species that rely mostly on benthic sources, the reliance on pelagic-derived sources may make Greenland Halibut more vulnerable to environmental changes (e.g., change in ice coverage and its impact on pelagic prey abundance or distributions, Bouchard et al. 2017). Consequently, the multi-species interactions of Greenland Halibut over large spatial and temporal scales make this species a suitable candidate to study how Arctic food webs respond to environmental changes.

\section{Acknowledgements}

We thank the crew of the F/V Frosti for their dedication and professionalism at sea, and the staff at Frosti Fishing Ltd. for technical and logistical support throughout the program. We also thank the science crew aboard, particularly those sampling the fishes (S. Atchison, S. MacPhee, C. Ruben, L. Edenfield), for their efforts under trying environmental conditions and Peter Rask Moller for zoarcid taxonomy. Finally thank the Inuvialuit of the western Canadian Arctic for their continued support of offshore Beaufort Sea research. This study was funded through the Beaufort Regional Environmental Assessment (a joint initiative of the Government of Canada and the 
Inuvialuit of the Western Canadian Arctic), the Environmental Studies Research Fund and Program on Energy Research and Development, both administered by Natural Resources Canada, and Fisheries and Oceans Canada (both regular program funding and International Governance Strategy strategic funding). Additional contributions through Arctic Net, Natural Sciences and Engineering Research Council of Canada (HS, MP) and scholarship to AS are acknowledged.

\section{References}

Amundsen, P. A., Gabler, H. M., \& Staldvik, F. J., 1996. A new approach to graphical analysis of feeding strategy from stomach contents data - modification of the Costello (1990) method. Journal of fish biology, 48(4), 607-614.

Barbeaux, S., Ianelli, J., Nichols, D., Hoff, J., 2012. Assessment of Greenland Turbot (Reinhardtius hippoglossoides) in the Bering Sea and Aleutian Islands. Seattle, WA Natl. Mar. Fish. Serv.

Barber, D.G., Hop, H., Mundy, C.J., Else, B., Dmitrenko, I.A., Tremblay, J.E., Ehn, J.K., Assmy, P., Daase, M., Candlish, L.M., Rysgaard, S., 2015. Selected physical, biological and biogeochemical implications of a rapidly changing Arctic Marginal Ice Zone. Prog. Oceanogr. doi:10.1016/j.pocean.2015.09.003

Bearhop, S., Adams, C.E., Waldron, S., FULLER, R. a., Macleod, H., 2004. Determining trophic niche width: A novel approach using stable isotope analysis. J. Anim. Ecol. 73, 1007-1012. doi:10.1111/j.0021-8790.2004.00861.x

Berestovskii, E. G, Anisimova N. A, Denisenko, C. G, Luppova, E. N, Savinov, V. M,

Timofeev, C. F., 1989. Relationships between size and body mass of some invertebrates and fish of the North-East Atlantic. Academy of Sciences of the USSR. Murman Marine Biological Institute, Apatity, pp 1-24

Bergstad, O. A., \& Bjelland, O., 1998. Trophic ecology of deepwater fishes associated with the 
continental slope of the eastern Norwegian Sea. ICES.

Boje, J., Neuenfeldt, S., Sparrevohn, C.R., Eigaard, O., Behrens, J.W., 2014. Seasonal migration, vertical activity, and winter temperature experience of Greenland halibut Reinhardtius hippoglossoides in West Greenland waters. Mar. Ecol. Prog. Ser. 508, 211-222. doi: $10.3354 /$ meps 10874

Bouchard, C., \& Fortier, L., 2011. Circum-arctic comparison of the hatching season of polar cod Boreogadus saida: a test of the freshwater winter refuge hypothesis. Progress in Oceanography, 90(1-4), 105-116.

Bouchard, C., Geoffroy, M., LeBlanc, M., Majewski, A., Gauthier, S., Walkusz, W., Reist, J., Fortier, L., 2017. Climate warming enhances polar cod recruitment, at least transiently. Prog. Oceanogr. 156, 121-129. doi:10.1016/J.POCEAN.2017.06.008

Boulva, J.,1979. Comparison of the Arctic cod (Boreogadus saida), the polar cod (Arctogadus glacialis) and the toothed cod (Arctogadus borisovi). Quebec, 79, 50.

Bowering, W.R., Lilly, G.R., 1992. Greenland Halibut (Reinhardtius-Hippoglossoides) Off Southern Labrador and Northeastern Newfoundland (Northwest Atlantic) Feed Primarily on Capelin (Mallotus villosus). Netherlands J. Sea Res. 29, 211-222. doi:10.1016/00777579(92)90021-6

Bowering, W.R., Nedreaas, K.H., 2000. A comparison of Greenland halibut (Reinhardtius hippoglossoides (Walbaum)) fisheries and distribution in the Northwest and Northeast Atlantic. Sarsia 85, 61-76. doi:10.1080/00364827.2000.10414555

Budge, S.M., Iverson, S.J., Bowen, W.D., Ackman, R.G., 2002. Among- and within-species variability in fatty acid signatures of marine fish and invertebrates on the Scotian Shelf, Georges Bank, and southern Gulf of St. Lawrence. Can. J. Fish. Aquat. Sci. 59, 886-898. doi:10.1139/f02-062 
Cherel, Y., Koubbi, P., Giraldo, C., Penot, F., Tavernier, E., Moteki, M., Ozouf-Costaz, C., Causse, R., Chartier, A., Hosie, G., 2011. Isotopic niches of fishes in coastal, neritic and oceanic waters off Adélie land, Antarctica. Polar Sci. 5, 286-297.

doi:10.1016/j.polar.2010.12.004

Chiperzak, D.B., Saurette, F., Raddi, P., 1995. First Record of Greenland Halibut (Reinhardtius hippoglossoides) in the Beaufort Sea (Arctic Ocean). Arctic 48, 368-371.

Christensen, O., Lear, W.., 1977. Bycatches in salmon drift-nets at West Greenland in 1972 [murres (Uria lomvia), dovekie (Plautus alle), shearwater (Puffinus gravis), black guillemot (Cepphus grylle), Atlantic puffin (Fratercula arctica), seabird, fish, Atlantic cod (Gadus morhua), harbo. Meddelelser om Groenl. (Denmark). v. 205(5).

Christiansen, J.S., Mecklenburg, C.W., Karamushko, O. V., 2014. Arctic marine fishes and their fisheries in light of global change. Glob. Chang. Biol. 20, 352-359. doi:10.1111/gcb.12395

Connelly, T.L., Deibel, D., Parrish, C.C., 2014. Trophic interactions in the benthic boundary layer of the Beaufort Sea shelf, Arctic Ocean: Combining bulk stable isotope and fatty acid signatures. Prog. Oceanogr. 120, 79-92. doi:10.1016/j.pocean.2013.07.032

Craig, H., 1957. Isotopic standards for carbon and oxygen and correction factors for massspectrometric analysis of carbon dioxide. Geochemica Cosmochim. Acta 12: 133-149.

Dahl, T.M., Falk-Petersen, S., Gabrielsen, G.W.G., Sargent, J.R.J., Hop, H., Millar, R.M., 2003. Lipids and stable isotopes in common eider, black-legged kittiwake and northern fulmar: a trophic study from an Arctic fjord. Mar. Ecol. Prog. Ser. 256, 257-269. doi:10.3354/meps 256257

Davoren, G.K., Montevecchi, W. a., 2003. Signals from seabirds indicate changing biology of capelin stocks. Mar. Ecol. Prog. Ser. 258, 253-261. doi:10.3354/meps258253

Dawe, E. G., Bowering, W. R., \& Joy, J. B., 1998. Predominance of squid (Gonatus spp.) in the 
diet of Greenland halibut (Reinhardtius hippoglossoides) on the deep slope of the northeast Newfoundland continental shelf. Fisheries Research, 36(2-3), 267-273.

de Groot, S.J., 1970. Some notes on an ambivalent behaviour of the Greenland halibut.

DeNiro, M., Epstein, S., 1981. Influence of diet on the distribution of nitrogen isotopes in animals. Geochim. Cosmochim. Acta.

DeNiro, M.J., Epstein, S., 1978. Influence of diet on the distribution of carbon isotopes in animals. Geochim. Cosmochim. Acta 42, 495-506. doi:10.1016/0016-7037(78)90199-0

Dwyer, K.S., Buren, A., Koen-Alonso, M., 2010. Greenland halibut diet in the Northwest Atlantic from 1978 to 2003 as an indicator of ecosystem change. J. Sea Res. 64, 436-445. doi:10.1016/j.seares.2010.04.006

Dwyer, K.S., Treble, M.A., Campana, S.E., 2016. Age and growth of Greenland Halibut ( Reinhardtius hippoglossoides ) in the Northwest Atlantic: A changing perception based on bomb radiocarbon analyses. Fish. Res. 179, 342-350. doi:10.1016/j.fishres.2016.01.016 Einarsson.H., 1945, "Euphausiacea. I. Northern Atlantic species." Dana Rep., (27): 1-185.

Falk-Petersen, S., Mayzaud, P., Kattner, G., Sargent, J.R., 2009. Lipids and life strategy of Arctic Calanus. Mar. Biol. Res. 5, 18-39. doi:10.1080/17451000802512267

Falk-Petersen, S., Pavlov, V., Timofeev, S., \& Sargent, J. R., 2007. Climate variability and possible effects on arctic food chains: the role of Calanus. In Arctic alpine ecosystems and people in a changing environment. pp. 147-166. Springer, Berlin, Heidelberg.

Falk-Petersen, S., Hopkins, C. C. E. and Sargent, J. R., 1990. Trophic relationships in the pelagic, Arctic food web. In “'Trophic relationships in marine environments'. M., Barnes and R. N., Gibson, eds.), Proceedings of the 24th European Marine Biology Symposium, Oban, Scotland, pp. 315-333. Aberdeen University Press.

Falk-Petersen, S., Sargent, J.R., Tande, K.S., 1987. Lipid composition of zooplankton in relation 
to the sub-arctic food web. Polar Biol. 8, 115-120. doi:10.1007/BF00297065

Folch, J., Lees, M., \& Sloane Stanley, G. H., 1957. A simple method for the isolation and purification of total lipids from animal tissues. J biol Chem, 226(1), 497-509.

Froese, R., Thorson, J.T., Reyes, R.B., 2014. A Bayesian approach for estimating length-weight relationships in fishes. J. Appl. Ichthyol. 30, 78-85. doi:10.1111/jai.12299

Geoffroy, M., Majewski, A., LeBlanc, M., Gauthier, S., Walkusz, W., Reist, J.D., Fortier, L., 2016. Vertical segregation of age- 0 and age-1+ polar cod (Boreogadus saida) over the annual cycle in the Canadian Beaufort Sea. Polar Biol. 39, 1023-1037. doi:10.1007/s00300$015-1811-\mathrm{Z}$

Giraldo, C., Ernande, B., Cresson, P., Kopp, D., Cachera, M., Travers-Trolet, M., Lefebvre, S., 2017. Depth gradient in the resource use of a fish community from a semi-enclosed sea. Limnol. Oceanogr. doi:10.1002/lno.10561

Giraldo, C., Stasko, A., Choy, E.S., Rosenberg, B., Majewski, A., Power, M., Swanson, H., Loseto, L., Reist, J.D., 2016. Trophic variability of Arctic fishes in the Canadian Beaufort Sea: a fatty acids and stable isotopes approach. Polar Biol. 39, 1267-1282. doi:10.1007/s00300-015-1851-4

Groot, S. D., 1970. Some notes on an ambivalent behaviour of the Greenland halibut Reinhardtius hippoglossoides (Walb.) Pisces: Pleuronectiformes. Journal of Fish Biology, 2(3), 275-279.

Hobson, K. a., Ambrose, W.G., Renaud, P.E., 1995. Sources of primary production, benthicpelagic coupling, and trophic relationships within the Northeast Water Polynya: insights from $\delta^{13} \mathrm{C}$ and $\delta^{15} \mathrm{~N}$ analysis. Mar. Ecol. Prog. Ser. 128, 1-10. doi:10.3354/meps128001

Hop, H., \& Gjøsæter, H., 2013. Polar cod (Boreogadus saida) and capelin (Mallotus villosus) as key species in marine food webs of the Arctic and the Barents Sea. Marine Biology 
Research, 9(9), 878-894.

Hussey, N.E., Macneil, M.A., Mcmeans, B.C., Olin, J. a., Dudley, S.F.J., Cliff, G., Wintner, S.P., Fennessy, S.T., Fisk, A.T., 2014. Rescaling the trophic structure of marine food webs. Ecol. Lett. 17, 239-250. doi:10.1111/ele.12226

Iken, K., Bluhm, B., Gradinger, R., 2005. Food web structure in the high Arctic Canada Basin: evidence from $\delta^{13} \mathrm{C}$ and $\delta^{15} \mathrm{~N}$ analysis. Polar Biol.

Iverson, S. J., Field, C., Don Bowen, W., \& Blanchard, W., 2004. Quantitative fatty acid signature analysis: a new method of estimating predator diets. Ecological Monographs, 74(2), 211-235.

Jørgensen, O. A., 1997. Pelagic occurrence of Greenland halibut, Reinhardtius hippoglossoides (Walbaum), in west Greenland waters. Journal of Northwest Atlantic Fishery Science, 21, $39-50$.

Kaartvedt, S., 2010. Diel Vertical Migration Behaviour of the Northern Krill (Meganyctiphanes norvegica Sars), in: Advances in Marine Biology. pp. 255-275. doi:10.1016/B978-0-12$381308-4.00009-1$

Karnovsky, N. J, Kwaśniewski, S, Węsławski, J. M, Walkusz, W, Beszczyńska-Mőller, A., 2003. Foraging behaviour of little auks in a heterogeneous environment. Mar Ecol Prog Ser, 253:289-303

Lansard, B., Mucci, A., Miller, L.A., Macdonald, R.W., Gratton, Y., 2012. Seasonal variability of water mass distribution in the southeastern Beaufort Sea determined by total alkalinity and $\delta^{18}$ O. J. Geophys. Res. Ocean. 117, n/a-n/a. doi:10.1029/2011JC007299

Libralato, S., Pranovi, F., Stergiou, K., Link, J., 2014. Trophodynamics in marine ecology: 70 years after Lindeman. Mar. Ecol. Prog. Ser. 512, 1-7. doi:10.3354/meps11033

Link, J., Bolles, K., Milliken, C., 2002. The feeding ecology of flatfish in the Northwest Atlantic. 
J. Northwest Atl. Fish. Sci, vol. 30, pp. 1-18.

Loseto, L. L., Stern, G. A., Connelly, T. L., Deibel, D., Gemmill, B., Prokopowicz, A.,... \& Ferguson, S. H., 2009. Summer diet of beluga whales inferred by fatty acid analysis of the eastern Beaufort Sea food web. Journal of Experimental Marine Biology and Ecology, $374(1), 12-18$.

Majewski, A.R., Atchison, S., MacPhee, S., Eert, J., Niemi, A., Michel, C., Reist, J.D., 2017. Marine fish community structure and habitat associations on the Canadian Beaufort shelf and slope. Deep Sea Res. Part I Oceanogr. Res. Pap. 121, 169-182.

doi:10.1016/j.dsr.2017.01.009

Majewski, A.R., Atchison, S.P., Suchy, K.D., Henry, J., MacPhee, S.A., Walkusz, W., Eert, J., Dempsey, M., Niemi, A., de Montety, L., Geoffroy, M., Giraldo, C., Michel, C., Archambault, P., Williams, W.J., Fortier, L., and J.D, Reist., 2016a. "Beaufort Sea Marine Fishes Project - Update for Stakeholders”. Fisheries and Oceans Canada, Ottawa. viii+57pp. Majewski, A.R., Walkusz, W., Lynn, B.R., Atchison, S., Eert, J., Reist, J.D., 2016b. Distribution and diet of demersal Arctic Cod, Boreogadus saida, in relation to habitat characteristics in the Canadian Beaufort Sea. Polar Biol. 39, 1087-1098. doi:10.1007/s00300-015-1857-y Majewski, A.R., Lynn, B.R., Lowdon, M.K., Williams, W.J., Reist, J.D., 2013. Community composition of demersal marine fishes on the Canadian Beaufort Shelf and at Herschel Island, Yukon Territory. J. Mar. Syst. 127, 55-64. doi:10.1016/j.jmarsys.2013.05.012 Mariotti, A., 1983. Atmospheric nitrogen is a reliable standard for natural $15 \mathrm{~N}$ abundance measurements. Nature 303: 685-687

McCann, K.S.K., Rasmussen, J.B., Umbanhowar, J., 2005. The dynamics of spatially coupled food webs. Ecol. Lett. 8, 513-523. doi:10.1111/j.1461-0248.2005.00742.x

McLaughlin, F.A., Carmack, E.C., 2010. Deepening of the nutricline and chlorophyll maximum 
in the Canada Basin interior, 2003-2009. Geophys. Res. Lett. 37, n/a-n/a. doi:10.1029/2010GL045459

McLaughlin, F.A., Carmack, E.C., Macdonald, R.W., Bishop, J.K.B., 1996. Physical and geochemical properties across the Atlantic/Pacific water mass front in the southern Canadian Basin. J. Geophys. Res. Ocean. 101, 1183-1197. doi:10.1029/95JC02634

McNicholl, D.G., Walkusz, W., Davoren, G.K., Majewski, A.R., Reist, J.D., 2016. Dietary characteristics of co-occurring polar cod (Boreogadus saida) and capelin (Mallotus villosus) in the Canadian Arctic, Darnley Bay. Polar Biol. 39, 1099-1108. doi:10.1007/s00300-015$1834-5$

Mecklenberg, C.W., Mecklenberg, T.A., Thorsteinson, L.K., 2002. Fishes of Alaska. American Fisheries Society. Bethesda, Maryland, USA.

Moore, J.W., Semmens, B.X., 2008. Incorporating uncertainty and prior information into stable isotope mixing models. Ecol. Lett. 11, 470-80. doi:10.1111/j.1461-0248.2008.01163.x

Morrison, W. R., \& Smith, L. M., 1964. Preparation of fatty acid methyl esters and dimethylacetals from lipids with boron fluoride--methanol. Journal of lipid research, 5(4), $600-608$.

Pedersen, S., Riget, F., 1993. Feeding habits of redfish (Sebastes spp.) and Greenland halibut (Reinhardtius hippoglossoides) in West Greenland waters. ICES J. Mar. Sci. 50, 445-459. doi:10.1006/jmsc.1993.1048

Petursdottir, H., Falk-Petersen, S., \& Gislason, A., 2012. Trophic interactions of meso-and macrozooplankton and fish in the Iceland Sea as evaluated by fatty acid and stable isotope analysis. ICES Journal of Marine Science, 69(7), 1277-1288.

Phillips, D. L., Inger, R., Bearhop, S., Jackson, A. L., Moore, J. W., Parnell, A. C., ... \& Ward, E. J., 2014. Best practices for use of stable isotope mixing models in food-web studies. 
Canadian Journal of Zoology, 92(10), 823-835.

Post, D.M., 2002. The long and short of food-chain length. Trends Ecol. Evol. 17, 269-277. doi:10.1016/S0169-5347(02)02455-2

Richter, C., 1994. Regional and seasonal variability in the vertical distribution of mesozooplankton in the Greenland Sea. Ber Polarforsch 154:1-90.

Romanuk, T.N., Hayward, A., Hutchings, J.A., 2011. Trophic level scales positively with body size in fishes. Glob. Ecol. Biogeogr. 20, 231-240. doi:10.1111/j.1466-8238.2010.00579.x

Scott, C. L., Falk-Petersen, S., Sargent, J. R., Hop, H., Lønne, O. J., \& Poltermann, M., 1999. Lipids and trophic interactions of ice fauna and pelagic zooplankton in the marginal ice zone of the Barents Sea. Polar Biology. 21(2), 65-70.

Solmundsson, J., 2007. Trophic ecology of Greenland halibut (Reinhardtius hippoglossoides) on the Icelandic continental shelf and slope. Mar. Biol. Res. 3, 231-242. doi:10.1080/17451000701477513

Stasko, A., Swanson, H., Majewski, A., Atchison, S., Reist, J., Power, M., 2016. Influences of depth and pelagic subsidies on the size-based trophic structure of Beaufort Sea fish communities. Mar. Ecol. Prog. Ser. 549, 153-166. doi:10.3354/meps11709

Stasko, A., Swanson, S., Atchinson, S., MacPhee, S., Majewski, A., de Montety, L., Archambault, P., Walkusz, W., Reist, J., Power, M., 2017. Stable isotope data $\left(\delta^{15} \mathrm{~N}, \delta^{13} \mathrm{C}\right)$ for marine fish and invertebrates from the Beaufort Sea Marine Fishes Project, AugustSeptember 2012 and 2013. Can. Data Rep. Fish. Aquat. Sci 1270: vi + 63 p.

Stock, B., Semmens, B., 2013. MixSIAR GUI user manual: version 1.0 Available from http://conserver.iugo-cafe.org/user/brice.semmens/MixSIAR.

Trueman, C., Johnston, G., O’Hea, B., MacKenzie, K., 2014. Trophic interactions of fish communities at midwater depths enhance long-term carbon storage and benthic production 
on continental slopes C. Proc. R. Soc. B 281, 20140669. doi:10.1002/rcm.2199

Vilhjálmsson, H., 1994. The Icelandic capelin stock: capelin, Mallotus villosus (Müller) in the Iceland-Greenland-Jan Mayen area. Hafrannsóknastofnunin.

Vollen, T., Albert, O., 2008. Pelagic behavior of adult Greenland halibut (Reinhardtius hippoglossoides). Fish. Bull.

Vollen, T., Albert, O.T., Nilssen, E.M., 2004. Diet composition and feeding behaviour of juvenile Greenland halibut (Reinhardtius hippoglossoides) in the Svalbard area. J. Sea Res. 51, 251259. doi:10.1016/j.seares.2003.08.006

Walkusz, W., Majewski, A., Reist, J., 2013. Distribution and diet of the bottom dwelling Arctic cod in the Canadian Beaufort Sea. J. Mar. Syst. 127, 65-75.

doi:10.1016/j.jmarsys.2012.04.004

Wassmann, P., Reigstad, M., 2011. Future Arctic Ocean Seasonal Ice Zones and Implications for Pelagic-Benthic Coupling. Oceanography 24, 220-231. doi:10.5670/oceanog.2011.74

Woodward, G., Benstead, J., Beveridge, O., 2010. Ecological networks in a changing climate. Adv. 


\section{Highlights}

- Greenland Halibut 'diet includes both pelagic and benthic sources.

- Low spatial (300 to $1500 \mathrm{~m}$ ) and temporal (years 2012-2014) variability was observed.

- Biomarkers (SIA, FA) indicate that halibut is a piscivorous/ opportunistic feeder.

- Halibut plays a major role in the benthic-pelagic coupling in the Canadian Arctic. 